SINAI Journal of Applied Sciences 9 (2) 2020 183-190

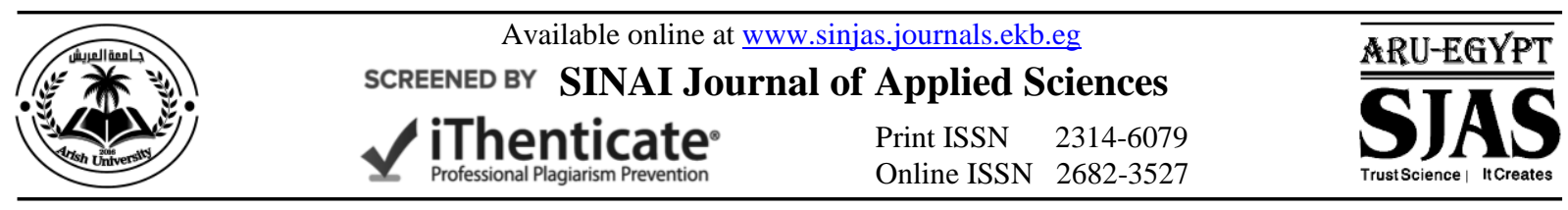

\title{
DETECTION OF LAND USE/COVER CHANGE IN BER EL-ABD AREA, NORTH SINAI, EGYPT USING REMOTE SENSING
}

\author{
Hend H. Abd El-Hameed ${ }^{1 *}$, E.R. Marzouk ${ }^{1}$, M. R. Abdo ${ }^{1}$ and A.B. Abdelmontaleb ${ }^{2}$ \\ 1. Dept. Soil and Water, Fac. Environ. Agric. Sci., Arish Univ., Egypt. \\ 2. Dept. Soil, National Authority for Remote Sensing and Space Sci., Cairo, Egypt.
}

\begin{tabular}{l} 
ARTICLE INFO \\
\hline Article history: \\
Received: $16 / 07 / 2020$ \\
Revised: $15 / 09 / 2020$ \\
Accepted: $15 / 09 / 2020$ \\
Available online: $15 / 09 / 2020$ \\
\hline Keywords: \\
Land use/land cover, \\
Change detection, \\
North Sinai, \\
Remote Sensing.
\end{tabular}

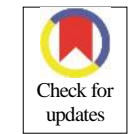

\begin{abstract}
Land use and land-cover (LULC) data provide essential information for environmental management and planning. Monitoring and detecting of landuse/land-cover changes and land degradation are very important for the planners, governments and the scientific communities, particularly where there are increasing pressures from human and natural activities on the adjacent environment. The present study aims to assess the changes of different land use/land cover classes for Ber El-Abd area in North Sinai, Egypt during the period from 1985 to 2018, to evaluate the impact of land cover change using remote sensing and GIS techniques. The results indicated that there was a regular trend characterized in most classes and that the change in different land use/land cover classes ranged between increase and decrease areas. A continuous increase in agricultural and urban areas and a continuous decrease in water bodies and sand dunes areas were detected in the studied area. The agricultural area recorded the highest increase during the period from 1985 to 2018 (69540 ha.) while it increased by 61306 ha. during the period from 2002 to 2018 . However, in urban area, the highest increase was recorded during the period from 1985 to 2018 followed by the period 2002-2018 with mean values of (1479 ha) and (1038 ha), respectively. The results showed that most of area have been significantly affected by the different classes of land use/land cover change due to agriculture activities, urban growth as a result of human activities dynamic impact.
\end{abstract}

\section{INTRODUCTION}

During the last two decades, the government was targeted to increase the agricultural production and its quality through increasing the agricultural area (Shalaby and Ali, 2010) and application of good agricultural practices. Currently, one of the most global serious problems that threaten food security within the region, if left untreated, is land degradation (Khalil $\boldsymbol{e t}$ al., 2014). Such changes are usually caused by human activities (e.g., urbanization, agriculture and overgrazing) (Abd Elhameed, 2015). These human induced changes can cause declines in natural resources and can affect food supply in these areas resulting in serious sociopolitical consequences (Turner et al., 2007). Remote sensing is very successful tools in agricultural field where digital data availability, for two decades minimum, in multiple wavebands of the spectrum and their large ground coverage makes it superior to field-based study (Khalil et al., 2014). Also, GIS technology provides a flexible tool for storing, analyzing and displaying digital data required for detection change and developing database. Satellite imagery has been used to monitor discrete land cover types via spectral classification or to evaluate land surface biophysical characteristics linear relationships with spectral reflectance or indices (Weng, 2001).

\footnotetext{
* Corresponding author: E-mail address: hend_hh2009@yahoo.com https://doi.org/10.21608/SINJAS.2020.36002.1002

(C) 2020 SINAI Journal of Applied Sciences. Published by Fac. Environ. Agric. Sci., Arish Univ. All rights reserved.
} 
Digital change detection encompasses the quantification of temporal phenomena from multi-date imagery that is most commonly acquired by satellite-based multi-spectral sensors (Coppin et al., 2004).

Change detection is an important process for monitoring and managing natural resources and urban development because it provides quantitative analysis of spatial distribution in the area of interest (Mahmoodzadeh, 2007).

Timely and accurate change detection of Earth's surface features provides the foundation for better understanding relationships and interactions between human and natural phenomena to better manage and use resources. Image differencing change detection technique is performed by subtracting the digital number (DN) value of a pixel in one date for a given band from the DN value of the same pixel for the same band of another date (Afify, 2011).

Change detection involves quantifying temporal effects using multi temporal data sets. When one is interested in knowing the changes over large areas and at frequent interval satellite data are commonly used. Results of the digital analysis to a large extent depend on the algorithms used (Minu and Shettya, 2015).

Post-classification with multi-temporal remote sensing images is one of the most popular change detection methods, providing the detailed "from-to" change information in real applications (Wu et al., 2017).

Land cover changes considered as one of the important global phenomena exerting perhaps one of the most significant effects on the environment than any other factor. It is, therefore, vital that accurate data on land cover changes are made available to facilitate the understanding of the link between land cover changes and environmental changes to allow planners to make effective decisions. The post classification approach is used to detect and assess land cover changes based on the comparative analysis of independently produced classification images of the same area at different dates (Alagu Raja et al., 2013).

The present study aims to assess the changes of different land use/land cover classes for Ber El-Abd area in North Sinai, Egypt during the period from 1985 to 2018, to evaluate the impact of land cover change using remote sensing and GIS techniques.

\section{MATERIALS AND METHODS}

\section{Study Area}

The studied area is located at the northern part of the Sinai Peninsula, bounded by longitudes $33^{\circ} 15^{\prime}$ and $32^{\circ} 45^{\prime}$ East, and latitudes $30^{\circ} 55^{\circ}$ and $31^{\circ} 15^{\prime}$ North, as shown in Fig. 1. Soils of North Sinai were classified into two orders: Aridisols and Entisols (Hassan, 2002). The Climatology data of the studied area taken from EMA (means for 1985- 2015). The studied area has typically arid and semi-arid climatic conditions (Mohamed, 2013). The maximum temperature is $31.9^{\circ} \mathrm{C}$ in Ber El-Abd station, as recorded in August, while the minimum temperature is $18.5^{\circ} \mathrm{C}$, as recorded in January. The mean temperature in winter ranges between $14.7^{\circ} \mathrm{C}$ to $16.6^{\circ} \mathrm{C}$. In summer, the mean temperature ranges between 24.4 to $24.7^{\circ} \mathrm{C}$. The soil temperature regime of the area could be defined as thermic and the soil moisture regime as torric. The natural vegetation in the studied area is very poor, and the most striking feature in the area is its barrenness.

\section{Data Collection}

Three different types of Landsat images (Landsat 5 TM, Landsat 7 ETM+, and Landsat 8 OLI TIRS) were obtained from the United States Geological Survey, United State Geological Survey (USGS) earth explorer website. Landsat $5 \mathrm{TM}$ images, consist of seven spectral bands with 


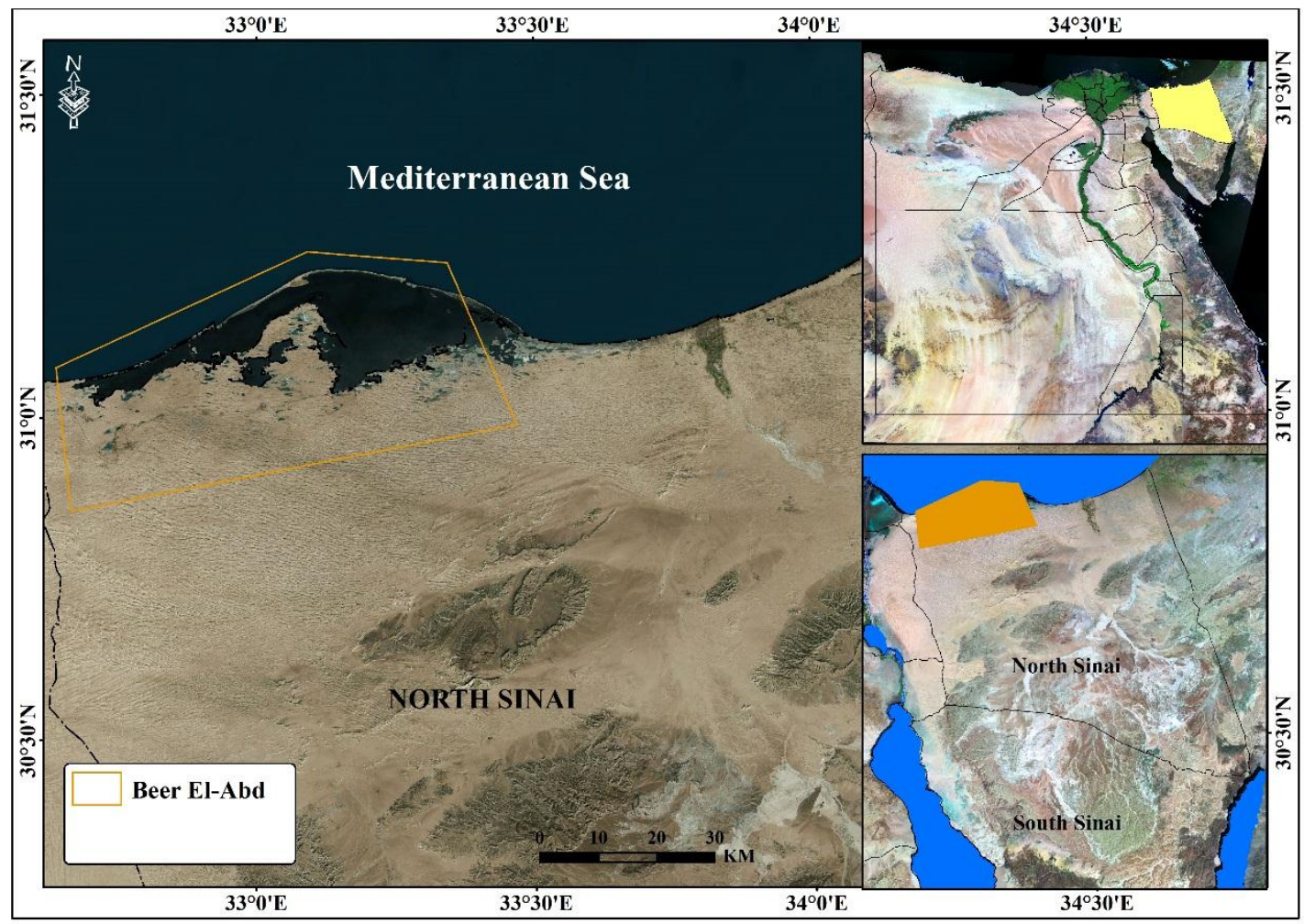

Fig. 1. Location of the study area

\section{Image Preprocessing}

Digital image preprocessing was manipulated by the used software. The atmospheric correction was done for visible, near infrared and shortwave infrared data in all different types of Landsat images. Atmospheric correction was done using FLAASH (Fast Line/of/ sight Atmospheric Analysis of Spectral Hypecubes) tool based on MODTRAN algorithm in ENVI 5.1.

\section{Image Processing}

Image processing was carried out using ENVI 5.4 software. An unsupervised classification was performed using the iterative self-organizing data analysis (ISODATA) algorithms in order to identify the classes that could be found in the study area, ISODATA unsupervised classification calculates class means evenly distributed in the data space then iteratively clusters the remaining pixels using minimum distance techniques. The different Landsat images in the study area were classified into nine different classes from land use/land cover (agricultural, urban, water bodies, sand dunes, sand sheet, sabkha, salt, island and sand bar).

\section{Post Classification Change Detection}

Comparison change detection was done after classifying the rectified images separately from three time periods (1985, 2002 and 2018). Each date of imagery was classified. The classified images were exported to the ArcGIS 10.4.1 software for vectorization, calculation and comparison of areas among the different dates, to identify various changes occurring in increase or decrease of land use/land cover.

\section{RESULTS AND DISCUSSION}

\section{Land Use/Land Cover Change Detection in Ber El-Abd Area in North Sinai}

The obtained classified images, after pre-processing and unsupervised classification 
indicated the different land use and land cover patterns in the studied area (Fig. 2). The change of different land use/land cover classes in the studied areas during the period from 1985 to 2018 were increased and decreased as a response to different activities. It indicated the results of classes; (sand dunes, sand sheet, water bodies, island, urban, agriculture, sabkha, sand bar and salts) were identified it is projected to estimate the different land use/land cover classes during the targeted periods (from 1985 up to 2002 and from 2002 to end of 2018). The classified images obtained after supervised classification, Fig. 2 and Table 1 show the results of land use/land cover of the studied area.

Concerning the agricultural area in Ber El-Abd; the results illustrated in Fig. 2 and Table 1 indicated that the highest estimated area was recorded in 2018, covering an area of $9.32 \%$ of the study area, followed by the years $2002(3.26 \%)$, and $1985(0.78 \%)$. In addition, the largest urban area was recorded in 2018 which represented $0.86 \%$ of the total study area, followed by the years 2002 and $1985(0.74 \%$ and $0.41 \%$, respectively). Regarding sand dunes areas 1985 recorded the largest area covering $82.39 \%$ of the study area, followed by the years 2002, (66.57\%) and 2018 (46.82\%). As for the sand sheet area 2018 recorded the largest area covering $35.35 \%$ of the study area, followed by the year 2002 and $2018(21.90 \%, 7.70 \%)$. The results of sabkha indicated that the year 1985 had the largest area (covered $4.80 \%$ of the total area) followed by the year2018 (3.91\%) and $2002(1.68 \%)$. Salt areas recorded in the year 2018 (covered $1.30 \%$ of the total area).

Regarding sand bar area, it was found that in 2002 the largest area estimated $3.55 \%$ of the total area, followed by 1985 which accounted for $2.45 \%$ and the year 2018 which represented $2.20 \%$ of the total area.

\section{Post classification change detection}

The classified images obtained after processing and classification change detection indicated the different land use and land cover patterns in the studied area (Table 2). The results showed a regular behavior that characterized the change in feature classes. The change of different land use/ cover classes in the studied areas during the period from 1985 to 2018 were increased and decreased as a response to different activities such as urban and land reclamation.

As for agricultural activities, the cultivated areas were significantly increased continuously during the period from 1985 to 2018 where the recorded rate of changes was (8829.66 fad.) and (25784 fad.) during 1985 - 2002 and 2002-2018, respectively. The total rate of change recorded for the period from 1985 to 2018 was (29206 fad.) (Table 2). These results could be attributed to agricultural expansion of desert land reclamation and the increase in population throughout the study period. Concerning urban area, the year of 2018 recorded the highest value followed by the year of 2002 and 1985. The rate of urban ration was increased in the period 1985-2002 by (185 Fed.) of the study area, while increased in the period 2002-2018 by (436 fad.). The total change rate in the period from 1985 2018 was (621 fad.) (Table 2). These results could be attributed to the urban sprawl, and to the negative outcomes of 2011 events. Also, the urban sprawl can be attributed to a number of factors, including the increasing population near the agricultural and safe areas, where there are conversions to urban class from most types of land classes.

Regarding sand dune area, the results illustrated in Table 2 indicated the opposite change pattern that was recorded for agricultural area where it decreased continuously from 1985 to 2018 with a total change of (-126604 Fed). The change rate for the periods from 2002 to 2018 and from 
Abd El-Hameed, et al. | SINAI Journal of Applied Sciences 9 (2) 2020 183-190

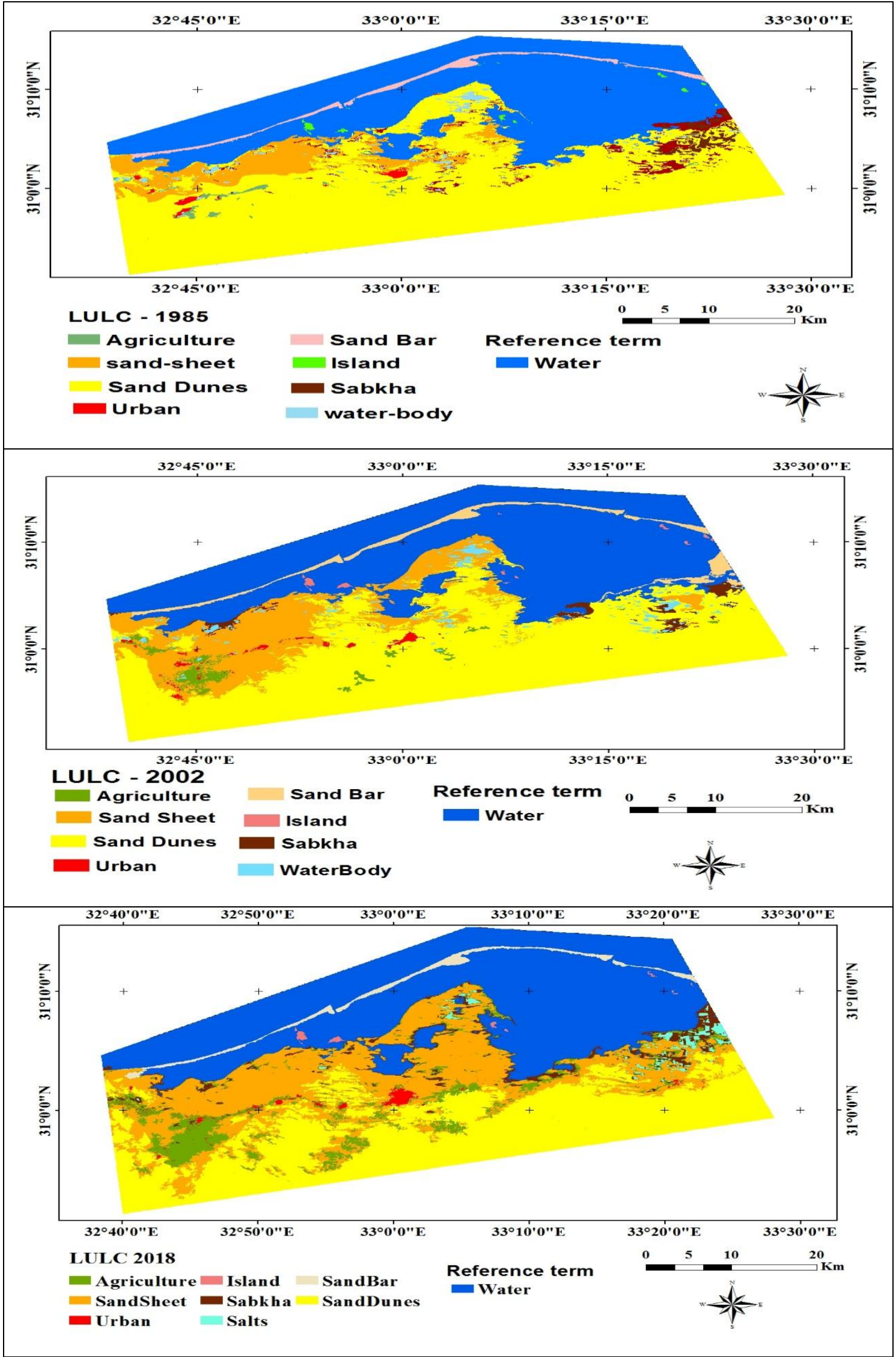

Fig. 2. Land use/ land cover map for the studied area in 1985, 2002 and 2018 
Table 1. Area of the different land use/covers classes in the studied area during the years of, 1985, 2002 and 2018

\begin{tabular}{|c|c|c|c|c|c|c|c|c|c|}
\hline \multirow[t]{3}{*}{ Class } & \multicolumn{9}{|c|}{ Target year } \\
\hline & \multicolumn{3}{|c|}{1985} & \multicolumn{3}{|c|}{2002} & \multicolumn{3}{|c|}{2018} \\
\hline & $\begin{array}{l}\text { Area } \\
\text { (fad.) }\end{array}$ & $\begin{array}{c}\text { Area } \\
\text { (ha.) }\end{array}$ & $\begin{array}{c}\text { Rate } \\
(\%)\end{array}$ & $\begin{array}{l}\text { Area } \\
\text { (fad.) }\end{array}$ & $\begin{array}{l}\text { Area } \\
\text { (ha.) }\end{array}$ & $\begin{array}{c}\text { Rate } \\
(\%)\end{array}$ & $\begin{array}{l}\text { Area } \\
\text { (fad.) }\end{array}$ & $\begin{array}{c}\text { Area } \\
\text { (ha.) }\end{array}$ & $\begin{array}{c}\text { Rate } \\
(\%)\end{array}$ \\
\hline Agriculture & 2776.02 & 1165.9 & 0.78 & 11603 & 4873.2 & 3.26 & 33160 & 13926.9 & 9.32 \\
\hline Urban & 1442 & 605.6 & 0.41 & 2627 & 1103.3 & 0.74 & 3063 & 1286.4 & 0.86 \\
\hline Water body & 4273.75 & 1794.9 & 1.20 & 7109 & 2985.7 & 2.00 & 0 & 0.0 & 0.00 \\
\hline Sand Dunes & 293219.5 & 123149.7 & 82.39 & 236925 & 99506.5 & 66.57 & 166615 & 69976.9 & 46.82 \\
\hline Sand Sheet & 27416.78 & 11514.8 & 7.70 & 77935 & 32732.0 & 21.90 & 125797 & 52833.7 & 35.35 \\
\hline Sabkha & 17087.84 & 7176.7 & 4.80 & 5984 & 2513.2 & 1.68 & 13912 & 5842.9 & 3.91 \\
\hline Salts & 0 & 0 & 0 & 0 & 0 & 0 & 4634 & 1946.2 & 1.30 \\
\hline Island & 985 & 413.7 & 0.28 & 1067 & 448.1 & 0.30 & 872 & 366.2 & 0.25 \\
\hline Sand Bar & 8701.84 & 3654.7 & 2.45 & 12650 & 5312.9 & 3.55 & 7847 & 3295.7 & 2.20 \\
\hline Total & 355900 & 149475.0 & 100 & 355900 & 149475.0 & 100 & 355900 & 149475.0 & 100 \\
\hline
\end{tabular}

Table 2. Change of the detection area during three periods for the studied area

\begin{tabular}{cccccccc}
\hline Class & \multicolumn{7}{c}{ Change area } \\
\cline { 2 - 7 } & $\begin{array}{c}\mathbf{1 9 8 5 - 2 0 0 2} \\
\text { fad. }\end{array}$ & $\begin{array}{c}\mathbf{1 9 8 5 - 2 0 0 2} \\
\text { ha. }\end{array}$ & $\begin{array}{c}\mathbf{2 0 0 2 - 2 0 1 8} \\
\text { fad. }\end{array}$ & $\begin{array}{c}\mathbf{2 0 0 2 - 2 0 1 8} \\
\text { ha. }\end{array}$ & $\begin{array}{c}\mathbf{1 9 8 5 - 2 0 1 8} \\
\text { fad. }\end{array}$ & $\begin{array}{c}\mathbf{1 9 8 5 - 2 0 1 8} \\
\text { ha. }\end{array}$ \\
\hline Agriculture & 8829.66 & 21023.42 & 21557 & 51327.22 & 30386.66 & 72350.64 \\
\hline Urban & 185 & 440.49 & 436 & 1038.12 & 621 & 1478.60 \\
Water body & 2835.25 & 6750.73 & -7109 & -16926.53 & -4273.75 & -10175.80 \\
Sand Dunes & -56294.5 & -134037.20 & -70310 & -167408.11 & -126604 & -301444.12 \\
Sand Sheet & 50518.22 & 120283.88 & 47862 & 113959.42 & 98380.22 & 234243.30 \\
Sabkha & -11103.8 & -26438.15 & 7928 & 18876.57 & -3175.84 & -7561.68 \\
Salts & 0 & 0.00 & 4634 & 11033.55 & 4634 & 11033.55 \\
Island & 82 & 195.24 & -195 & -464.30 & -113 & -269.05 \\
Sand Bar & 3948.16 & 9400.57 & -4803 & -11435.94 & -854.84 & -2035.37 \\
\hline
\end{tabular}


1985 to 2002 recorded (-70310 fad.) and (56294.5 fad.), respectively. As for sand sheet, the areas were significantly increased continuously during the period from 1985 to 2018 where the recorded rate of changes was (50518.22 fad.) and (47862 fad.) during 1985-2002 and 2002-2018, respectively. The total rate of change recorded for the period from 1985 to 2018 was (98380.22 fad.).

Data showed that the sabkhas exhibited different patterns of change. the area was decreased in 2002 compared to that of the area in 1985 with change rate of $(-11103.8$ fad.) whereas it increased in 2018 compared to 2002 recording change rate of $(7928$ fad.). However, salts area in 2018 remained lower compared to that in 1985 . The total rate of change during the period from 1985 to 2018 was (-3175.84 fad.).

\section{Conclusion}

It could be concluded that satellite data is a good and quick technique to monitor the changes in land use/land cover with low cost comparing to conventional surveying methods. The results also showed that most of studied area have been affected by the different categories of land cover such as agriculture, urban, water bodies and sand areas. Also, it is recommended that continuous remote sensing images collection, analysis interpretation and updating of images is required to monitor the developments for quick response in decision making by appropriate authorities.

\section{REFERENCES}

Abd Elhameed, H.H. (2015). Spatial variation of well water contamination based on microbiological and chemical indicators in North Sinai region. M.Sc. Thesis, Soil and Water Dept., Fac. Agri., Suez Canal Univ., Egypt.

Afify, H.A. (2011). Evaluation of change detection techniques for monitoring land- cover changes: A case study in new Burg El-Arab area. Alex. Eng. J., 50: 187-195.

Alagu Raja, R.A; Anand, V.; Senthil K.A.; Sandeep, M.V.; Abdelaziz, R. and Bakr, M.I. (2013). Inverse modeling of groundwater flow of Delta Wadi ElArish. J. Water Res. and Prot., 4: 432438.

Coppin, P.; Jonckheere, I.; Nackaetts, K.; Muys, B. and Lambin, E. (2004). Digital change detection methods in ecosystem monitoring: a review. Int. J. Remote Sens., 25 (9):1565-1596.

Hassan, M.A. (2002). Environmental Studies on Coastal Zone Soils of the North Sinai Peninsula (Egypt) using remote sensing techniques. Ph.D. Thesis, Soil and Water Dept., Fac. Agri., SCU, Ismailia, Egypt.

Khalil, A.A.; Essa, Y.H. and Hasaean, M.K. (2014): Monitoring agricultural landegradation in Egypt using MODIS NDVI satellite images. Nat. Sci., 12 (8): $15-21$.

Mahmoodzadeh, H. (2007). Digital change detection using remotely sensed data for monitoring green space destruction in Tabriz. International J. Environ. Res., 1 (1): 35-41.

Minu, S. and Shettya, A. (2015). A Comparative study of image change detection Algorithms in MATLAB. International conference on water resources, coastal and ocean engineering (ICWRCOE 2015). Aquatic Procedia, 4: 1366 - 1373.

Mohamed, E.S. (2013). Spatial assessment of desertification in North Sinai using modified MEDLAUS model. Arab J. Geosci., 6:4647-4659. DOI 10.1007/ s12517-012-0723-2

Shalaby, A. and Ali, R.R. (2010). Agricultural land monitoring in Egypt using NOAAAVHRR and SPOT vegetation data. Nat. Sci., 8 (11): 275-278. 
Turner, B.L.; Lambin, E.F. and Reenberg, A. (2007), The emergence of land change science for global environmental change and sustainability. PNAS 104, 20666-20671.

Weng, Q. (2001). Land use change analysis in the Zhujiang Delta of China using satellite remote sensing, GIS and stochastic modelling. J. Environ. Manag., 64: 273-284.

Wu, Y.; Chen, J.; Ji, J.; Gong, P.; Liao, Q.; Tian, Q. and Ma, H. (2017). A Mechanism study of reflectance spectroscopy for investigating heavy metals in soil. Soil Sci. Soc. Ame. J., 17.

\footnotetext{
الملخص العربي

تحديد التغيير في استخدام الأرض والغطاء الأرضي في منطقة بئر العبد، شمال سيناء، مصر باستخدام الاستشعار من بعد منط

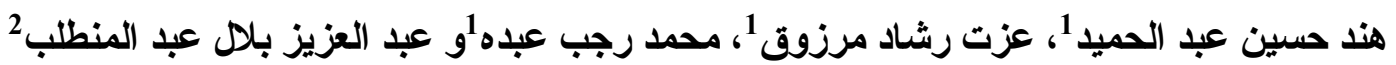

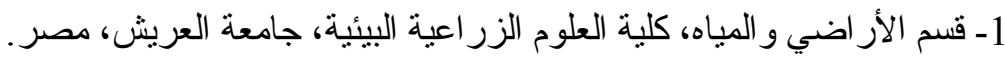

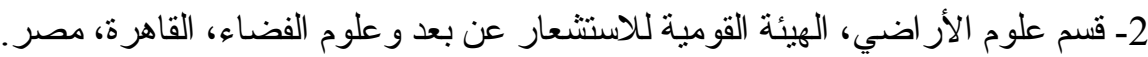

توفر بيانات استخدام الأر اضي و الغطاء الأرضي معلومات أساسية للإدارة و التخطيط البيائيين، يعد رصد وكثيف

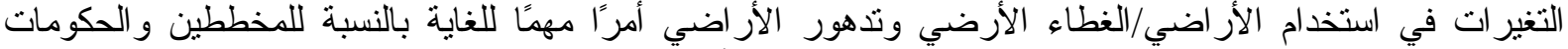

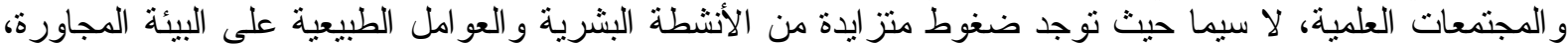

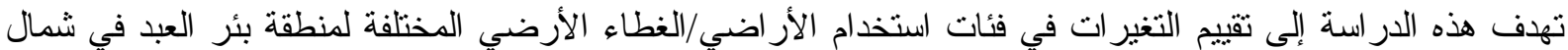

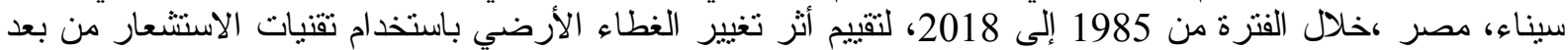

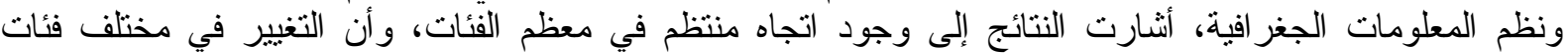

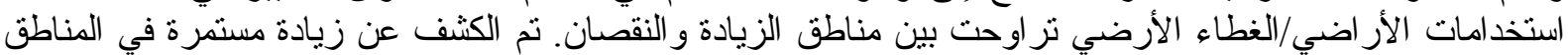

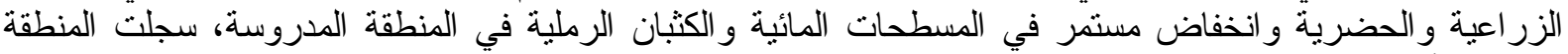

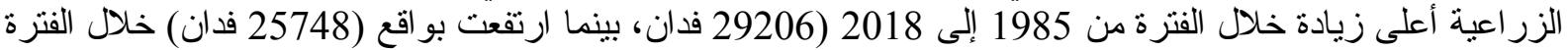

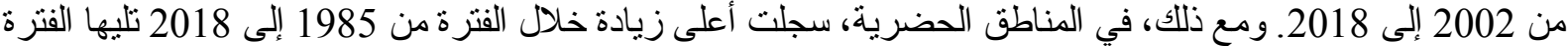

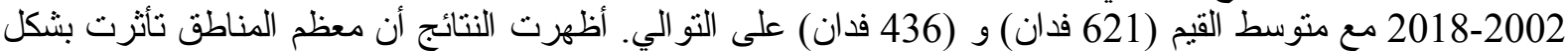
كبير بفئات مختلفة من استخدامات الأر اضي/تغير الغطاء الأرضي بسبب الأنشطة الزر اعية و النمو الحضري نتيجة لتأثير الأنشطة البشرية. الكلمات الاسترشادية: استخدام الأرض، الغطاء الأرضي، كثف التغيير ، شمال سيناء، الاستشعار من بعد.
} 